\title{
Estimation of the rare status of Iris aphylla L. according to the categories and criteria of the IUCN Red list in the western and eastern edge of the East European plain
}

\author{
Stepan Senator ${ }^{1 *}$, Sergey Savchuk ${ }^{2}$, and Vladimir Lebed'ko ${ }^{2}$ \\ ${ }^{1}$ Tsitsyn Main Botanical Garden, Russian Academy of Sciences, 127276, Moscow, \\ Botanicheskaya st., 4 \\ ${ }^{2}$ V.F. Kuprevich Institute of experimental botany of National Academy of Sciences of \\ Republic of Belarus; 220072, Belarus, Minsk, Akademicheskaya st., 27
}

\begin{abstract}
The article contains information on assessing the environmental status of Iris aphylla populations according to the categories and criteria of the IUCN Red List. It was found that in Gomel Oblast (Republic of Belarus) and Samara Oblast (Russian Federation), I. aphylla is characterized as "Vulnerable" (VU). The resulting categories reflect the specifics of regional conditions affecting populations.
\end{abstract}

\section{Introduction}

Iris aphylla L. (Iridaceae) is a European forest-steppe species, widely distributed in the center and in the south of the European part of Russia, Ukraine, while in other European countries its populations are much less common [1-3]. The species is interesting from an environmental point of view, since it is coenotically associated with multi-species communities of meadow steppes and their petrophytic (calcephitic) variants [4], whose representatives, in turn, are one of the most threatened in Europe due to natural (climatic, environmental) and anthropogenic reasons [5, 6]. This article contains information on assessing the environmental status of Iris aphylla populations according to the categories and criteria of the IUCN Red List. As it is known [7], rarity status categories serve as a kind of "markers" that determine priorities in the conservation of species, and also to a certain extent affect the recommended protection measures.

\section{Materials and methods}

Iris aphylla is a species that is highly variable from a morphological point of view, as indicated by the presence of numerous synonyms and four distinguished subspecies [2]. At the same time, the absence of significant genetic differences between central and marginal populations makes it possible to consider Iris aphylla as a single species [1].

*Corresponding author: stsenator@yandex.ru 
To assess the rarity status according to the categories and criteria of the IUCN Red List, we selected Iris aphylla populations located on the western and eastern outskirts of the East European Plain - in the Republic of Belarus (Gomel Oblast) and the Russian Federation (Samara Oblast).

Iris aphylla is included in the Red Book of the Republic of Belarus [8] with category 1 of national environmental importance (a taxon having a very low or rapidly declining population, the preservation of which is impossible without special measures; the national population has high international significance), Red Book of the Russian Federation [9] with category $2 \mathrm{a}$ (a taxon, the number of which is reduced as a result of changes in the conditions of existence or destruction of habitats) and the Red Book of Samara Oblast [10] with category 3 is a rare species. Called Iris aphylla subsp. hungarica Hegi species is included in the European Red List of Vascular Plants [11] with the category DD (Data Deficient).

In the Republic of Belarus, 4 locations are known situated along the Pripyat and Dnieper rivers in a distance from the main part of the range $[3,12,13]$. In Samara Oblast, 14 locations are reliably known $[14,15]$, the eastern border of distribution passes here.

The Gomel Oblast is located in the south-east of Belarus between 51.262407$53.350769^{\circ} \mathrm{N}$ and $27.250474-31.798795^{\circ} \mathrm{E}$ and borders on Bryansk Oblast of Russia, as well as Kiev, Chernigov and Zhytomyr Oblasts of Ukraine. In terms of botany and geography, the territory is located on the border of the Eurasian taiga (coniferous) and European broad-leaved regions, the identified growth sites of Iris aphylla are confined to the latter [16]. The climate is moderately continental, with an average temperature of January $-6.0^{\circ} \mathrm{C}$, July $-18.0^{\circ} \mathrm{C}$, and an average annual precipitation of 550-660 $\mathrm{mm}$ [17].

Samara Oblast is located in the South-East of the European part of Russia in the middle reaches of the Volga River between $51.394780-54.678116^{\circ} \mathrm{N}$ and $47.927147-$ $52.566598^{\circ} \mathrm{E}$. In terms of botany and geography, the territory is located on the border of the European broad-leaved forest and the Eurasian steppe regions. The climate is moderately continental with an average monthly temperature of January $-13.8^{\circ} \mathrm{C}$ and July $-20.7^{\circ} \mathrm{C}$. The average annual temperature is $3.8^{\circ} \mathrm{C}$, and the average annual precipitation is $372 \mathrm{~mm}$ [18].

To identify the distribution of Iris aphylla in the research areas the funds of the herbaria of V.F. Kuprevich Institute of experimental botany of National Academy of Sciences of Republic of Belarus (MSK), Lomonosov Moscow State University (MW), Komarov Botanical Institute of the RAS (LE), Institute of Ecology of the Volga river basin of the RAS (PVB), as well as the data contained in the information-analytical system Salix [15], are studied.

Iris aphylla is natural for the selected regions, so can be evaluated. The status was assessed according to the criteria and categories of the IUCN Red list [19], taking into account the experience and recommendations of some researchers [20,21].

\section{Results}

To assess the threat of extinction of Iris aphylla at the regional level in Belarus, according to the IUCN criteria, indicators such as range, habitat area and number of locations can be used. The number of generative individuals in known localities is fairly stable. We do not have information about a sharp decline in the number of species, as well as about other dynamic phenomena in populations. Recently, a new location of Iris aphylla has been identified [13], but we should not talk about expanding the range either; judging by the habitat (oakery on the top of the mane in the floodplain of the river Dnieper), it is likely that the species is present here for a long time, and its detection is directly proportional to the detail of floral research. In this regard, the application of criteria A (population reduction) 
and $\mathrm{B}$ (range reduction) cannot be used. It is also not possible to apply criteria C (limited numbers that are declining) and $\mathrm{E}$ (quantitative analysis of the probability of extinction). Thus, the only criterion that can be applied is criterion D (strong population/range restriction).

Since the distribution area of Iris aphylla on the territory of the Republic of Belarus does not exceed $20 \mathrm{sq} \mathrm{km}$, and its population consists of 4 localities (excluding the location indicated for the vicinity of the Turov town by I.K. Pachosky [22], which is probably identical to the vicinity of Storozhevtsy village), then this satisfies the requirements of subcriteria D2 of category VU (Vulnerable).

Thus, an initial assessment of the threat of extinction of Iris aphylla in Belarus made it possible to obtain the VU D2 category. All localities of this species in Belarus are confined to Gomel Oblast and are located only in three districts (Petrikovsky, Zhitkovichsky and Rechitsky). Despite the fact that two localities are under the protected regime of the Pripyatsky National Park and the condition of all of them is quite stable, they are usually very small and have the slightest influence of negative anthropogenic (falling, cutting, etc.) and natural (succession changes) factors for a short period of time can lead to a critical condition or even complete disappearance.

To assess the threat of extinction of Iris aphylla the Samara Oblast, criteria A (reduction in numbers) and B (restriction of range) are not applicable. The number of individuals in known localities is stable. The species distribution area is $1962.0 \mathrm{sq} \mathrm{km}$ (which satisfies the requirements of subcriterion $\mathrm{B} 1$ ), however, the remaining characteristics are not suitable for assessment by criterion B, since the number of known localities exceeds the limit values for the VU category (Vulnerable). It is also impossible to apply the criteria D (strong limitation of the number / range) and E (quantitative analysis of the probability of extinction) - the number of species in the region exceeds 250 individuals, and there are no statistical forecasts of the risk of its extinction. Thus, the only criterion for the application of which is possible is $\mathrm{C}$ (limited numbers).

Since the abundance of a species in known localities is, as a rule, up to 30 partial shoots, it can be assumed that its total abundance in the Samara Oblast does not exceed 500 generative individuals, which corresponds to criterion $\mathrm{C}$ of the EN category (Disappearing). Within criterion $\mathrm{C}$, the species corresponds to indicator "i" of condition "a" of subcriteria 2, which indicates the absence of Iris aphylla populations in the region consisting of more than 250 generative individuals, as well as indicator "ii", according to which $90-100 \%$ are in one micropopulation of generative individuals.

The initial assessment of the threat of extinction of Iris aphylla in Samara Oblast allowed obtaining the EN C2a (i,ii) category. At the same time, most localities in the region are situated on the right bank of the Volga river and only one in the left bank. There is a high probability that the study area is periodically carried out unhindered migration of diasporas from conspecific populations of the neighboring Ulyanovsk Oblast - in fact, a single natural complex, that is, there is a "rescue effect", as a result of which the threat category can be lowered to VU "Vulnerable". Thus, Iris aphylla in Samara Oblast has a category of threat: VU C2a (i,ii). The species is protected on the territory of only eight natural monuments of regional significance, which may be the reason for the deterioration of the conservation status of the taxon.

\section{Conclusion}

Application of the criteria and rarity categories of the IUCN Red List made it possible to identify the status of Iris aphylla at the regional level (in Gomel Oblast of Belarus and Samara Oblast of the Russian Federation). In both cases, the species under investigation 
was rated VU Vulnerable. The resulting categories reflect the specifics of regional conditions affecting populations.

We are aware of only three regions in Eastern Europe that evaluated the regional status of the rarity of Iris aphylla: the Caucasus (under the name Iris furcata Bieb., Category NE) [23], the Krasnodar Krai (under the name I. furcata, EN; A2ac; B2ab (iii)) [24] and the Republic of Mordovia (NT; C2a (i)) [21]. We hope that this work will draw the attention of researchers to assessing the status of rarities of Iris aphylla in other regions, which in the future will help to more accurately determine its category in the European Red List of Vascular Plants.

\section{References}

1. A. Wryblewska, P1 Syst Evol 272, 49-65 (2008).

2. E.V. Boltenkov, Phytotaxa 273, 141-143 (2016).

3. M.V. Kazakova, N.A. Sobolev, A.S. Kugusheva, Botanicheskiy zhurn. 104, 124-146 (2019)

4. M.V. Kazakova, N.I. Zolotukhin, A.V. Poluyanov, A.S. Kugusheva, Ecological and coenotic characteristics of Iris aphylla L. habitats on the Central Russian upland, in Proceedings of the VII International symposium "Steppes of Northern Eurasia", IS UB RAS, 27-31 May 2015 Orenburg, Russia (2015)

5. M. Pärtel, H.H. Bruun, M. Sammul, Biodiversity in temperate European grasslands: origin and conservation. In: R. Lillak, R. Viiralt, A. Linke, V. Geherman (eds.) Integrating efficient grassland farming and biodiversity. Estonian Grassland Society, Tartu (2005)

6. Ł. Kajtoch, E. Cieślak, Z. Varga, W. Paul, M.A. Mazur, G. Sramkó, D. Kubisz, Biodivers Conserv 25, 2309-2339 (2016)

7. D.V. Gel'tman, Botanicheskiy zhurn. 102, 875-888 (2017)

8. Red Book of the Republic of Belarus (Minsk, 2015)

9. Red Book of the Russian Federation (plants and fungi) (Moscow, 2008)

10. Red Book of Samara Oblast. Plants and fungi (Samara, 2017)

11. M. Bilz, S.L. Kell, N. Maxted, R.V. Lansdown, European Red List of Vascular Plants (Luxembourg, 2011).

12. D.V. Dubovik, in Flora Belarusi. Vascular plants. 3, 190-230 (2017)

13. D.V. Dubovik, S.S. Savchuk, A.N. Skuratovich, V.N. Lebed'ko, New locations of rare and protected species of vascular plants of the Belarusian flora, in Botanika (issledovaniya), 4 (2015)

14. M.V. Kazakova, N.A. Sobolev, T.I. Varlygina, V.M. Vasyukov, A.Ya. Grigor'evskaya, N.I. Zolotukhin, A.S. Kugusheva, A.V. Maslennikov, L.A. Maslennikova, T.V. Nedosekina, A.V. Poluyanov, N.M. Reshetnikova, A.S. Sokolov, L.A. Sokolova, Yu.E. Shubina, Distribution of Iris aphylla L. on the Russian plain, in Proceedings of Ryazan branch of The Russian Botanical Society, 4, Ryazan, Russia (2017)

15. S.A. Senator, S.V. Saksonov, V.M. Vasyukov, Flora of the Middle Volga Region [Electronic resource]. Version 3 (2020) Available at: https://саликс.pф

16. V.S. Gel'tman, Geographical and typological analysis of forest vegetation in Belarus (Minsk, 1982)

17. V.F. Loginov, The climate of Belarus (Minsk, 1996) 
18. The climate of Samara Oblast and its characteristics for climate-dependent sectors of the economy (Samara, 2006)

19. IUCN Standards and Petitions Committee. 2019. Guidelines for Using the IUCN Red List Categories and Criteria. Version 14. Prepared by the Standards and Petitions Committee.

https://nc.iucnredlist.org/redlist/content/attachment_files/RedListGuidelines.pdf

20. A.A. Zavarzin, E.E. Muchnik, Botanicheskiy zhurn. 90, 105-118 (2005)

21. A.A. Khapugin, T.B. Silaeva, E.V. Vargot, G.G. Chugunov, G.A. Grishutkina, O.G. Grishutkin, E.V. Pis'markina, Yu.S. Orlova, Nature Conserv. Research, 2 (2017)

22. I.K. Pachoskiy, Flora of Polesie and surrounding areas, in Proceedings of the Saint Petersburg Society of naturalists. Department of Botany, 30, Sankt-Peterburg, Russia (1900)

23. Red List of the Endemic plants of the Caucasus: Armenia, Azerbaijan, Georgia, Iran, Russia and Turkey (St. Louis, 2013).

24. Red Book of Krasnodar Kray. Plants and fungi (Krasnodar, 2017). 